\title{
Фразеологизми с орнитонимском саставницом у српском језику
}

Aвstract: Štrbac Gordana, Frazeologizmi s ornitonimskom sastavnicom u srpskom jezi$k u$ (Phraseologisms with the Name of the Bird in Serbian Language). "Poznańskie Studia Slawistyczne" 20. Poznań 2021. Publishing House of the Poznań Society for the Advancement of the Arts and Sciences, Adam Mickiewicz University, pp. 71-89. ISSN 2084-3011.

The subject of this paper is phraseology with the name of the bird in its lexical structure (such as crn kao gavran, držati se kao pokisli vrabac, zaplesti se kao pile u kučine, podmetnuti kukavičje jaje etc.). These units were analyzed in order to present the language picture of the animal world of Serbian speakers. The research is based on linguocultural approach to language - Zykova's conceptual theory of phraseology and culture (Зыкова, 2015). Attention is mostly paid to the problem of motivation of the observed phraseologisms and the phraseological semantic processes. There are several different types of information that motivate the creation of phraseology with the name of the bird as their lexical component: the appearance of the bird, its sound and behavior, as well as its symbolic value.

KEYwORDS: language picture of the world; phraseology; the name of the bird; cultural information; Serbian language

\section{1. Уводне напомене}

Лингвокултуролошки приступ језику постулира изразит антропоцентризам унутар којег се интересовање с објекта, тј. језичког система и његове структуре, премешта на субјекат, тј. његовог носиоца. У лингвокултурологији централно место заузима појам језичке слике света, који има дугогодишњу историју и сложено порекло (Бартмињски, 2011, 41-42). У његовој основи је идеја о језику као манифестацији човековог доживљаја стварности ${ }^{1}$. Предмет овог истраживања

${ }^{1}$ То је, заправо, интерпретација стварности одражена у језику, у виду судова о свету, људима, стварима, догађајима. Та интерпретација је истовремено субјективна, јер је 
управо су фразеологизми у чијем се лексичком саставу налази орнитоним, тј. назив одређене врсте птице (или придев изведен од њега, нпр. кукавичји, вранин). Циљ је да се семантичком анализом посматраних фразеолошких јединица (какве су нпр. врана је коме мозак попила, живети као голубови, имати пилећи мозак) утврде представе о овој врсти животиња карактеристичне за говорнике српског језика, које су због своје изражености и јасне профилисаности ушле у семантички простор језика. За ову прилику анализи је подвргнуто око осамдесет јединица, ексцерпираних из једнојезичних дескриптивних и фразеолошких речника српског (српскохрватског) језика².

У фразеолошкој семантици могуће је уочити површински или семантички и дубински или концептуални ниво, при чему је други место настанка фразеолошке слике, али и место спајања фразеолошког знака с концептуалним фондом културе те тачка непосредног утицаја концептосфере културе на формирање фразеолошког значења. Посматрајући језик и културу као два одвојена семиотичка система, Ирина Зикова фразеолошко значење види као резултат међусемиотичке транспозиције, која подразумева прелазак садржаја из једног семиотичког система у други, а у случају фразеологизама - из система културе у систем језика ${ }^{3}$. Међусемиотичка транспозиција заснива се

резултат субјективне перцепције, и интерсубјективна, пошто је друштвено прихваћена и као таква уграђена у вредносни систем једне заједнице (Бартмињски, 2011, 46). За Ј. Д. Апресјана то је наивна слика, јер се у многим суштинским детаљима разликује од научне (Апресян, 1995, 352).

${ }^{2}$ Као примарни извори грађе послужили су Речник српскохрватског књижевног и народног језика САНУ и Речник српскохрватског књижевног језика Матице српске, а као контролни - фразеолошки речници Ј. Матешића (Маtešić, 1982) и Ђ. Оташевића (2012). Према коришћеним речницима навођена су и фразеолошка значења. Из првобитног корпуса изостале су фразеолошке јединице које су регионално и временски маркиране. Када је реч о варијантности на свим нивоима, узете су у обзир форме које су потврђене у савременом српском језику. Иначе, у овом истраживању фразеологизму се приступа не само као јединици секундарне номинације, која као таква учествује у структурирању једног језичког слоја, већ и као носиоцу одређених когнитивних и културних информација. Ова слојевитост фразеологизма проистиче из мотивисаности његовог значења, у чијој су основи типска представа, која има улогу денотата, и сликовна гешталт структура, с улогом квазиденотата - типска представа описује свет, а сликовна гешталт структура подсећа на њега у имагинацији (Телия, 1996, 191-213).

${ }^{3}$ Она се одвија у неколико узастопних операција индивидуално-колективне свести: избор концептуалног садржаја (из различитих семиотичких области оваплоћења 
на специфичностима унутрашње организације макрометафоричних концептуалних модела као извора сликовитости. У реконструкцији фразеолошког значења, утврђивањем одговарајућих метафоричних модела, могуће је издвојити два основна типа културних информација које се добијају на два различита начина спознаје света: доживљавањем и разумевањем. Доживљавање света остварује се као емоционално-чулно, душевно и естетско, док разумевање света може бити архетипско, митолошко, религиозно, филозофско и научно (Зыкова, $2015,41-55)^{4}$. С обзиром на описане појединости развоја семантике, на фразеологију се у науци гледа као на ,један од најважнијих извора за реконструкцију језичке слике света” (Мршевић-Радовић, 2008, V).

\section{2. Фразеолошка слика птице у српском језику}

У лексичком саставу посматраних фразеологизама налази се хипероним птица, генеричког значења 'кичмењак обрастао перјем, с крилима, кљуном и са две ноге', као и његови хипоними: врабаи, врана, гавран, голуб, гуска, детао/детлић, кокошка (кока, квочка, кокош), крешталица, кукавица, лабуд, ласта, патка, петао, пиле, соко, сврака, чавка (чавче), цева. Најбројнији су фразеологизми са хиперонимом птица (има их двадесетак), за њима следе изрази са зоонимима $^{5}$ кокошка (кока, квочка, кокош) (15), врабаи (9), гуска (7), петао (6).

концептосфере културе); његова синтеза; структурирање и стварање сложеног концептуалног образовања које се састоји из одређеног система међусобно повезаних простијих и сложенијих концептуалних саставница (Зыкова, 2015, 91-101).

${ }^{4}$ Културна информација, у макрометафоричким концептуалним моделима фразеолошких слика, има хијерархијску организацију: емоционално-чулна информација $\rightarrow$ $\{$ архетипска + митолошка + религиозна + филозофска + научна информација $\} \rightarrow$ етичка + естетичка информација $\Sigma$ 'одобравање' / 'неодобравање'. Њен почетак је емоционално-чулна информација, а својеврстан резултат њеног оформљења етичка и естетска информација (Зыкова, 2015, 233).

${ }^{5}$ У хрватској фразеолошкој литератури покушава се направити разлика између термина зоонимна и анималистичка фразеологија, будући да се термин зооним односи на име, а не на назив животиње. Узимајући то у обзир, И. Видовић Болт напомиње следеће: „predlažemo da se animalističkim frazemima naziva skupina ustaljenih desemantiziranih sveza u sastavu kojih je naziv životinje (zoonimska komponenta), dio životinjskog tela (somatska komponenta) odnosno izvedenica (pasji, konjski i sl.). Naime, ni tijekom 
У осталим случајевима број фразеолошких јединица с лексичком компонентом која се односи на неку врсту птице знатно је мањи. Овом фразеолошком групом денотирају се и квалификују физичка и психичка својства људи, али и појаве ван самог човека. Семантичком анализом фразеолошког значења настоји се утврдити информациона база за њихову мотивацију. То могу бити утисци о реалним особинама птица (нпр. о њиховом изгледу и понашању), као и ирационалне, стереотипне, симболичке и друге представе о њима.

ВЕЛИЧИНА ПТИЦЕ И ДРУГЕ ТЕЛЕСНЕ ПОЈЕДИНОСТИ. У свестИ ГОВОрНИКа српског језика птица је еталон количине, што је мотивисано њеним минијатурним изгледом. Она је мера количине коју човек може унети у организам односно мера његове тежине. Садржаји 'јести врло мало' односно 'брз; лаган', исказани поредбеним фразеологизмима јести као птица / јести као врабаи и лак као птица, развијени су по метафоричном моделу човек је птица, где је повезивање људског и животињског домена утемељено на обележјима ‘мало' и ‘лак'․ Паралелан метафорични модел делује и у случају када циљни домен припада категорији живо(-): добити врапца 'ништа не добити'.

Као што је утврђено, говорници српског језика птицу опажају, пре свега, као малену животињу. Из ове слике рађа се представа о птици као плашљивом и крхком створењу, које је спремно да нестане и на најмањи шум. Одређене групе људи идентификују се с птицом управо на основу лакоће реаговања на спољашње надражаје: спавати као птица на грани 'спавати лаким, немирним сном'. Крхка грађа малених животиња асоцијативно се повезује и с карактерним особинама као што су благост и попустљивост, према метафоричном моделу конкРЕТНО $\rightarrow$ АПСТРАКТНО, што је праћено позитивном конотативном вредношћу: мекан као пиленце 'врло, попустљив'.

rasprava na skupu Animalistički frazemi u slavenskim jezicima održanom 21. i 22. ožujka 2014. u Zagrebu nije iznađen termin koji bi u frazeološkom kontekstu bio prihvatljiviji od već ustaljenog termina zoonim za naziv životinje kao frazemske sastavnice" (Vidović Bolt, 2014, 1).

${ }^{6}$ Према С. Гољак $(2013,496)$, десна компонента поредбеног фразеологизма указује на функционисање система лексема еталона заступљених у фразеологији, као и на активност одређених лексичких група, што представља важну типолошку карактеристику језика. 
Међутим, сићушан изглед не мора нужно подразумевати афирмативну експресију. Оно што је мало у свести говорника често се доживљава као безначајно и безопасно, на основу чега се формира семантика следећих фразеолошких израза: заклати кога као врапца (пиле) 'убити некога без околишања' и наудиће му (јој и сл.) као врабаи гуски 'ништа му (јој и сл.) не може, не представља за њега (њу и сл.) никакву опасност'. Исти принцип видљив је и у случају када физичка и физиолошка недораслост учествују у концептуализацији неспособности сналажења и решавања проблема, те смушености и сметености - (c)плести (заплести) се као пиле у кучине 'смести се, беспомоћно се збунити, заплести се у безизлазан, положај, бити збуњен'.

Добро ухрањена патка или гуска постаје у свести говорника мера богатства и материјалне добити: крекнула дебела гуска коме 'доћи до великог добитка, наследства', убити (заклати) масну патку 'добро зарадити'. У процесу фразеологизације за формирање семантике од посебног је значаја придевска одредба (дебео, мастан) уз зооним, која асоцира на благостање и сигурност ${ }^{7}$. У примерима овог типа метафорична веза између изворног и циљног домена БоГАТА ГозБА $\rightarrow$ МАТЕРИЈАЛНА ДОБРоБИТ заснована је на имплицираној метонимијској узрочно-последичној релацији да добро ухрањена животиња гарантује обилан оброк.

Боја као људска телесна карактеристика односно као карактеристика предмета асоцира на боју птичјег перја: иарен као детао/детлић 'врло шарен', ирн као гавран 'јако, посве црн ${ }^{8}$. Ова врста визуелне

${ }^{7}$ Израз новинска (новинарска) патка у значењу 'измишљена, неистинита вест', забележен у коришћеним речницима, у српском језику показује тенденцију ка својеврсној терминологизацији с обзиром на специфичност своје семантике (тј. истакнуту референцијалност) и функционалностилску обележеност. Евентуално може припадати жаргонском слоју новинске терминологије. У сваком случају, израз испољава извесну семантичку и прагматичку специјализованост и не излази из медијског домена, што показују следећи примери његове употребе у новинама: Јучерашња вест о започетој истрази против наручиоца убиства Ћурувије обична [је] новинарска патка; Тај продаваи ће бити и купаи, па нема никаквог резона да подиже иену станова. То су само новинарске патке и спекулације појединих агената (http://www.korpus.matf.bg.ac.rs). Његова мотивација за говорнике српског језика потпуно је непрозирна. М. Шипка (1998, 271-273) порекло овог израза тражи у француском и немачком језику.

${ }^{8}$ Асоцијација на црну боју једна је од најизраженијих код говорника хрватског језика кад је реч о називу наведене птице као стимулусу (v. Barčot, 2017, 192-196). 
информације може послужити као изворни домен за метафорично упућивање на апстрактне категорије. Како је црна очекивана и уобичајена боја враниног перја, бела врана доживљава се као потпуно неуобичајена и ретка појава. Тако постоји израз бела врана у значењу 'велика реткост, нешто врло необично, велики изузетак', којим се још може означити и особа, која се по својим цртама личности, постигнућима, понашању и сл. издваја од околине 9 . Овај израз изграђен је на основу архетипске опозиције црно/бело, која симболизује непомирљиве супротности између особина или понашања својствених појединцу и оних који су карактеристични за његову околину, при чему се на датог појединца, из угла говорника, гледа с благонаклоношћу. Стога се овим фразеологизмом исказује неодобравање према самом процесу издвајања, тј. негативно се вреднује сам поступак искључивања, спроведен од стране средине, који говорник сматра неправедним, што се види на основу примера из медијског и књижевноуметничког дискурса: Аустрија је била месецима бојкотована, третирана као бела врана и потом принуђена да Хајдера практично искључи из политичког живота; Улав је за НАТО бела врана јер је жестоко писао у норвешкој штампи против бомбардована Србије; Крвљу сам заслужио тај проклети официрски чин, а међу официрима сам био као бела врана. Они ме, Ђубрета, никад нису сматрали за себи равна, устезали су се да ми пруже руку (http://www.korpus.matf.bg.ac.rs). Иначе, мотив беле вране везује се за грчку митологију ${ }^{10}$.

Спољашњи изглед животиње поистовећује се са изгледом човека, нарочито у одређеним психофизиолошким стањима као што су позно старосно доба или непријатна расположења: стара кокош 'стара жена'"11, (држати се [изгледати и сл.]) као покисла кокош / као покисли врабаи 'бити потиштен, утучен, увређен' 12 .

${ }^{9}$ УП. фразеологизам цирна овц̧а.

${ }^{10}$ Аполон, којем је врана донела вест о невери његове љубавнице Корониде, обојио је у црно целу врсту, која је до тада била бела, сматрајући вест лажном. Када се уверио у њену истинитост, вранама се искупио тако што их је учинио светим птицама и весницима смрти (Kovačević, 2015, 32).

${ }^{11}$ Кокошка је везана за тајну рођења, због чега се у фолклорном стваралаштву повезује са женом (Раденковић, 1996, 106).

${ }^{12}$ Фразеологизам држати се (изгледати и сл.) као покисла кокош може се објаснити и на основу веровања да перје не може заштити кокошку од кише. У фолклору 
Изузетна способност визуелног опажања концептуализује се помоћу сокола: соколово око (око соколово) 'добар, оштар вид, добро запажање' ${ }^{13}$. Иако ова птица има и своје симболичке вредности, у језичкој слици оне нису видљиве. Израз је настао највероватније на основу људског искуства у додиру са овом животињом, која показује изражену вештину хватања плена с велике висине, што потврђује веома добру визуелну перцепцију ${ }^{14}$.

ОГЛАшАВАњЕ ПтицЕ. Утисци о оглашавањУ Птица, примљени аудитивном перцепцијом, изворни су домен за говорну активност. Пошто се на овај начин концептуализује по садржају бесмислен говор, као и говор који се одвија без прекида, у мотивационој структури фразеологизма налазе се називи оних птица које испуштају непријатан звук: блебетати (брбљати) као крешталица 'којешта, свашта говорити'15 и брбљати као чавка 'много, без прекида говорити' ${ }^{\prime 6}$.

У примеру отићи где петли не певају 'отићи негде где људи не живе, отићи у недођију’ оглашавање петлова, као и њихово присуство, асоцирају на познату, блиску средину и дом. Одсуство ове животиње, која је симбол дома и домаћинства, сигнал је непознатог и дивљег окружења. Према Т. Ђорђевићу, од све живине у нашем народу највише се гаји кокошка, без које се егзистенција људи не може ни замислити: „Мисли се да тамо где петао не пева нема ни људи. Тамо су пусти крајеви" (Ђорђевић, 1958, 59). Уз то, Љубинко Раденковић $(1996,105)$

постоји прича да се Христос, бежећи од Чивута, сакрио под кокошје крило. Кокошка је раширила крила и открила га, због чега ју је Христос проклео да перјем не може себе сакрити. Како је склониште нашао под птичјим крилом, Христос је благословио птицу: за твоје перје вода не приањала. Перје кокошке, међутим, натапа се водом па кад неко покисне, каже се: покиснуо као кокот (Ђорђевић, 1958, 60).

${ }^{13}$ Могуће је још и значење 'човек који добро види и запажа'.

${ }^{14}$ Да је соко еталон изванредне способности визуелног опажања, потврђују и одговори хрватских испитаника (v. Barčot, 2017, 202-206).

${ }^{15}$ И сам глагол крештати, који је у основи зоонима јер му се примарна семантика 'испуштати оштар, висок и храпав глас' везује првенствено за оглашавање птица, као секундарно развија значење говорне активности 'говорити, викати високим, пискавим или промуклим гласом'.

${ }^{16}$ На стимулус чавка међу хрватским испитаницима знатан број одговора односи се управо на неугодан звук, крештање, грактање, брбљивост (Barčot, 2017, 188-192). У чешком језику исти концепт вербализује се фразеологизмом с лексемом гуска (v. Bunk, Opašić, 2010). 
истиче да кокошка као домаћа животиња носи јаку социјалну обележеност.

Израз лабудова песма, који има метафорично значење 'последњи важнији рад или дело пре смрти (на крају активног стварања неког уметника, научног радника); последње дело', мотивисан је необичним понашањем ове птице која у смртној опасности испушта милозвучне тонове. Ова птица, као и њено оглашавање, чест је мотив митова, предања и спевова, од древне Грчке до Сибира, преко Мале Азије и словенских и германских народа. У њима се лабуд слави као неокаљана птица, чија су белина, снага и љупкост епифанија светлости, због чега Јунг закључује да је песма соларне птице лабуда митолошко представљање етимолошког изоморфизма светлости и речи (Gerbran, Ševalije, 2013, 473-476). Примери из електронског корпуса (махом из медијског дискурса) показују да овај израз може указати и на било коју врсту успеха, у било ком сегменту стварности, који се сматра последњим у низу: Успела [je] да се врати освојивши титулу у Паризу, али је то, по свему судећи, била лабудова песма франиуске тенисерке. Од тада Морезмо није успела да постигне значајнији резултат (http://www.korpus.matf.bg.ac.rs).

КРЕТАњЕ ПтИцЕ. Информације које се тичу простора кроз који се птица креће, добијене визуелним опажањем, подстакле су настанак фразеолошког обрта из птичјега лета са спацијалним прилошким значењем 'с висока, из висине, одозго, из птичје перспективе', где је очигледно метонимијско транспоновање жиВотињскО КРЕТАњЕ НА ВИСИни $\rightarrow$ ВИСИнА.

Ситуациони облици кретања птица подстичу развој метафоричне фразеолошке семантике из домена људског кретања: $и ћ и$ (пролазити и сл.) као гуске 'ићи у реду, ићи један за другим', гушчји поредак (след) 'кретање у реду, један за другим', корачати као сита патка 'гегати се', ићи као гуска (гуске) у маглу 'ићи сасвим неодређено и несигурно, ${ }^{17}$. Последњи пример, међутим, може имати и значење 'предузети, предузимати шта не размишљајући много', које је потврда специфичног начина концептуализације људских интелектуалних особина.

${ }^{17}$ Овде припада и колоквијално обележени израз вући се (и сл.) као усрани голуб 'споро и невољно се кретати'. 
ПоНАШАњЕ ПтицЕ. Мотивациону основу фразеолошких израза чине и одређени урођени или устаљени облици понашања птица, према којима често постоји однос омаловажавања и неодобравања. Помоћу ове слике концептуализују се навике и особине људи према којима говорници имају исти такав однос, нпр. седети (лежати) као квочка (на јајима) 'проводити време у ленствовању, излежавању', украо би испод кокоши јаје 'врло је вешт лопов'. У другом примеру степен испољавања људске особине мери се преданошћу с којом кокошка обавља своју примарну функцију. Појачану ноту негативне експресивности носи фразеологизам дробити ћоравој квочки, чије се значење 'радити узалудан посао' развија на основу контраста међу садржајима исказаним лексемама дробити и ћорава.

Навика да се рано леже или устаје односно уопште временски периоди ране вечери или јутра концептуализују се преко исте навике која је својствена поменутим животињама, уз додатно увођење мушког представника дате врсте: ићи с кокошима спавати 'легати на починак већ у први сумрак', с кокошима лећи, с петловима устати 'рано лећи, рано устати', с петловима устајати 'рано устајати', пре првих петлова 'до ране зоре', у прве (друге, треће) петлове 'у рану зору'18.

Метонимијска веза послЕдицА зА узРок, праћена експресивним односом омаловажавања, у основи је фразеолошке семантике 'сматрати кога неспособним за нешто', коју развија израз не дати коме (ни) гуске пасти.

Посебно занимљиву групу представљају фразеологизми чија семантика почива на поменутом метафоричном моделу човЕК ЈЕ ПтицА, изграђеном на идеји да се међу људима, с обзиром на склоности и понашање, може спровести одређена класификација, што је својствено птицама и другим представницима животињског света. Осим опажајних процеса у овој врсти концептуализације учествује и научни облик

${ }^{18}$ Иако у базној структури нема елемената којима се експлицира оглашавање петлова, оно се у овом случају подразумева. Према Т. Ђорђевићу $(1958,66)$, певање петлова, које се одвија ноћу, служило је као врста ноћног сата, помоћу којег су се људи временски оријентисали. У том смислу, знало се које је време када запевају први, други или трећи петлови, мада не постоји у свим крајевима потпуна сагласност којем добу одговара које оглашавање. Иначе, о певању петлова у нашем народу постоји читав низ веровања (v. Ђорђевић, 1958; Раденковић, 1996). 
мишљења, којем је својствен управо таксономски односно меронимски принцип систематизације и категоризације стварности. Ови фразеологизми су у форми синтагме, с именицом птиияа као управним чланом и придевским, именичким или неким другим детерминатором као зависним чланом, који на нефразеолошком плану функционише као класификатор, док се на фразеолошком нивоу њиме упућује на специфичност одређене врсте људи. Тако се фразеологизмом фина птица, изграђеном на иронији, квалификује лукава и препредена особа; израз ноћна птица описује особу која већи део ноћи проводи изван куће; за особу која се често сели из места у место употребљава се фразеологизам птица селища; на ретке особине људи упућује се фразеолошком синтагмом ретка птица ${ }^{19}$; човек који ружно говори о својој земљи или о свом народу назива се птицом која блати своје гнездо. У ситуацијама када се жели истаћи да се човекове особине најочигледније испољавају кроз његов рад, односно да се о њему може говорити на основу резултата тог рада, користи се израз каква птииа таква песма.

Изразито негативан однос говорника према врапцу одражава израз дрзак (безобразан) као врабаи 'врло дрзак, безобразан', формиран на основу човековог сазнања о његовом понашању, које се испољава као упорно и наметљиво.

Специфично понашање птице у односу према људима може послужити као мотивациона појединост за настанак фразеолошких јединица - хајати (марити) за кога, за шта као врана за скелецију 'нимало не марити за кога, за шта'.

Порекло фразеологизама подметати (подметнути, потурити) коме кукавичје (кукавичко) јаје 'вешто подметати, подметнути' и подмеће као кукавица јаје 'свој терет, своје обавезе, пребацује, намеће другом’ треба тражити управо у необичном понашању ових птица, које своја јаја полажу у туђа гнезда како би се тамо излегли млади које ће тада отхранити други родитељи. При томе је утврђено да младунци

${ }^{19}$ Ово је дослован превод латинског израза rara avis, који постоји и у другим европским језицима. Према речима Б. Ковачевић, овај фразеологизам, као и израз бела врана, има античко порекло те се може рећи да представља хипероним за све фразеологизме код којих се на структурном плану појављује појединачан назив за птице с контрастом прототипичне боје (Kovačević, 2015, 32). 
кукавице избацују из гнезда осталу младунчад како би обезбедили сигурнији опстанак.

СТЕРЕОТИПНЕ ПРЕДСТАВЕ О ПТИЦАМА. МеђУ називима за поједине врсте птица у фразеолошком корпусу доминира зооним кокошка (кока/ кокош/квочка). Изразито негативан однос према овој животињи изражавају фразеологизми којима се обележава умна ограниченост човека. Примери показују да је у српској култури кокошка (уз пиле, паче 20 и свраку) еталон људске глупости ${ }^{21}$ б бити кокошје (naчје, пилеће, плитке) памети 'бити неспособан за нормално логично расуђивање, бити умно ограничен и слабе памети', имати кокошји (сврачји ${ }^{22}, n u$ лећи) мозак 'бити умно ограничен, приглуп', кокомје памћење 'слаба памет', кокошји поглед 'закрчен, устајао мозак, дух'. Претпоставља се да је птица уопште у српској језичкој заједници послужила као средство помоћу којег се концептуализује умна ограниченост управо због своје величине. У основи оваквог поимања налази се идеја да на интелектуалне активности утиче величина органа у којем се оне одвијају. Метафора глуП човек ЈЕ ПтицА, изникла из метонимијске везе ОРГАН ЗА Сволу ФунКцију, утемељена је управо на овој врсти аналогије ${ }^{23}$. Исти садржај преноси и пример с нефразеолошком сликом у којој дата животиња има моћ да одузме човеку памет: кокош је коме $n a$ мет (мозак) позобала 'изгубити памет, побудалити'. Варијантним се

\footnotetext{
${ }^{20}$ Иако пиле и паче, како истиче И. Видовић Болт, сами по себи нису носиоци непожељних интелектуалних способности, негативну конотираност устаљених десемантизованих спојева одредило је пејоративно метафорично значење зоонимске лексеме као назива домаће животиње. Према речима ове ауторке, човек је спремнији да домаћој животињи припише људске особине, у првом реду непожељне, него дивљим животињама од којих често зазире (Vidović Bolt, 2014, 9).

${ }^{21} \mathrm{~V}$. Ђорђевић, 1958, 60. У белоруској фразеологији у улози еталона глупости јавља се врана: дурная варона (Голяк, 2007, 189). Међујезичке лексичке разлике у фразеологизмима повезане су с културном компонентом у семантици речи (Гољак, 2013, 496).

22 У животињској слици света говорника српског језика сврака има непожељну квалификацију: сматра се птицом крадљивицом, а својим крештањем може људима да најави долазак гостију (Раденковић, 1996, 151). Уз то, она је синоним за брбљивицу: свраке су жртвоване Баху да би се уз вино развезали језици и откриле тајне. У легенди коју је испричао Овидије могуће је видети симбол зависти, уображености, блебетања и снобизма (Gerbran, Ševalije, 2013, 922-923). Иначе, сељаци сматрају свраку штеточином јер пије јаја из кокошјег гнезда и односи живину, због чега је уништавају (Ђорђевић, 1958, 57).

${ }^{23}$ Исти семантички принцип постоји и у другим језицима (v. Vidović Bolt, 2014).
} 
могу сматрати фразеологизми: није коме (ваљда) сврака мозак попила 'не бити луд, бити нормалан, знати шта треба радити', врана је коме мозак (памет) испила (попила) 'бити глуп'. На формирање значења утицала је слика људског мозга који због мале величине птица може позобати/попити (Vidović Bolt, 2014, 5).

Значај и вредност неке теме односно предмета умањује се управо употребом фразеологизма с називом птице: о томе (већ) и врапщии (на крововима) цьвкућу (певају) / то већ и врапци знају / гуске знају 'нешто је већ сваком познато'. Фразеолошка семантика развија се на основу имплицитне стереотипне представе о птицама као животињама ограничених интелектуалних способности. Ниподаштавајући однос према овој животињи открива се у изразу кокошји кашаљ, којим се упућује на неважну ствар, ситницу, маленкост ${ }^{24}$.

Насупрот претежно негативном односу према кокошци, пример дати коку за јаје ‘преварити се, направити лош посао' потврда је афирмативног односа, а развија се на основу веровања да је кокошка повезана с богатством, са златом (Раденковић, 1996, 107). У усменом стваралаштву златна кока или мотив коке која носи златна јаја веома је чест, па се претпоставља да је могао надахнути и наведени израз.

Примери: голуб (голубица, соко) из вранина гнезда 'особа без вредности, плашљива, кукавица' и као врана међу голубовима 'различит, од свих осталих', фразеолошку семантику развијају на основу опозиције позитивна/негативна концептуализација, коју заступају зооними у лексичком саставу фразеологизама (голуб/голубииа/соко врана). На истом концептуалном и семантичком моделу почива израз подметнути (подвалити) коме чавче под голуба 'преварити кога, подвалити коме, дати друго а не оно што би се желело’.

У животињској слици света према ласти, као и према голубу, постоји изразито позитиван однос ${ }^{25}$. Међутим, овај стереотипни однос није видљив у самом језику и његовим јединицама. У језик је уткано веровање да је ласта весница пролећа те се у том контексту може

${ }^{24}$ У српском језику се ипак овај садржај чешће преноси изразом мачји кашаљ.

${ }^{25}$ Ласта је чиста, света птица. Она је, као и голуб, омиљена Богу и слави га својим певањем. Њен цвркут доживљава се као молитва. Има функцију заштитнице куће и стоке (Толстој, Раденковић, 2001, 333; детаљније о ласти у народном предању v. Ђорђевић, 1958, 21-32). 
разумети фразеологизам прва ласта, који се реализује у значењу 'први наговештај, претеча у каквој ствари', добијен метафоричним транспоновањем мотивационог, нефразеолошког садржаја у фразеолошки. Према народном веровању, ласта почиње пролеће, а славуј га завршава. У песмама је названа кључарком зато што преко мора доноси златне кључеве којима отвара лето и затвара зиму (Толстој, Раденковић, 2001, 333).

СИМБоЛИЧКА УЛОГА ПтИцЕ (у РЕЛИГИЈском контЕКСту). Летење Птице одређује њену симболичку везу између неба и земље те се као симбол небеског света супротставља змији као симболу земаљског света. У различитим религијама она симболизује анђеле, виша стања бића (Gerbran, Ševalije, 2013, 755-756) ${ }^{26}$.

Из визуелног опажања начина кретања, које се одвија у ваздуху, на висини, без ометања и ограничења, али и из виђења птице као живог симбола божанске слободе, лишене земаљских случајности (Gerbran, Ševalije, 2013, 756), проистиче представа о птици као еталону слободе, независности и безбрижности. Тиме су мотивисани фразеологизми поредбеног типа бити (осећати се, живети) као птица на грани, слободан као птица (на грани), живети као птица небеска у значењу ‘бити слободан, независан' и 'безбрижно живети'27. Дакле, фразеолошки семантички садржаји развијају се на основу симболичког потенцијала птице којем је у основи метафорични модел човеК ЈЕ ПтицА, надограђен метонимијском транспозицијом: животињА слоБодног, НЕОГРАНИЧЕНОГ КРЕТАњА $\rightarrow$ СЛОБОДА, НЕЗАВИСНОСТ.

${ }^{26}$ У глобалном моделу света симболички статус животиња одређује се на два основна начина: 1. први обухвата вертикални распоред према дрвету света као универзалном симболичком класификатору; 2. други је хоризонтални распоред изведен на основу удаљености животиње у односу на човека. У првом случају, заснованом на опозицијама горе/доле, на/под, суво/мокро, у културама индоевропских народа животиње се распоређују на следећи начин: на врху дрвета света или на његовим гранама налазе се птице, у средини или на нивоу стабла распоређени су копитари, у доњем делу, тј. у корену, смештене су змије, жабе, мишеви, рибе итд. Хоризонтална подела укључује следећи распоред: најдаље од човека јесу петао и кокошка, а најближи му је коњ (Раденковић, 1996, 85-86).

${ }^{27}$ У позадини је слика гнезда на врху стабла као раја, тј. најузвишенијег боравишта у које ће душа ступити ако успе да долети до њега ослободивши се људског терета, из чега следи да је душа схваћена као птица селица (Gerbran, Ševalije, 2013, 756). 
Божанска симболика птице уткана је у фразеологизам друге би коме птице (данас) певале са метафорично добијеним значењем 'у другим, у бољим приликама би се неко налазио', изведеним поистовећивањем природног амбијента који настаје оглашавањем птица са околностима које окружују човека. Он се може разумети ако се узме у обзир да је језик птица заправо језик богова односно духовно сазнање (Gerbran, Ševalije, 2013, 755). Тиме се животне околности стављају у руке божанске силе, пред којом је човек немоћан, а спознаја божанске истине у великој мери предодређује људски опстанак.

Религијска представа птице као божанског гласника садржана је и у изразу прича о ирвеном врапиу у значењу 'бајка, улепшано причање', који Драгана Мршевић-Радовић повезује с бајком Црвени врабаи. У њој цар поставља захтев тројици синова да му за новосаграђену цркву набаве црвеног врапца, који ће у њој певати. Бајка, па самим тим и фразеологизам који се из ње развио, одражава симболички карактер птице: врабац повезује „овај” и „онај” свет. „Црква је слика небеског Јерусалима, небеског града у којем столује Христос као господар света, па се може претпоставити да 'умилни глас' врапца треба да симболизује његову божанску присутност” (Мршевић-Радовић, 2008, 16) 28 .

Синтагма птичје млеко као конституент фразеолошких израза којима се указује на богатство и изобиље (немати само птичјег млека, имати и птичјег млека 'имати свега, живети у изобиљу') односно на незајажљивост (тражити од птице млека / тражити птичјег млека 'тражити нешто немогуће, бити незасит') показатељ је религиозних облика мишљења утканих у језик. У литератури се наведени изрази доводе у везу с грчким извором: Грци су говорили да на Самосу, чувеном по вину и сваком изобиљу, има и од „пилета млека”. Дата синтагма алудира на фантастичне, рајске пределе, у чије су постојање веровали и сами Словени. То је чудесан простор, у који птице и змије одлазе преко зима, а замишљан је као 'обрнути свет', у којем је све могуће, којим теку млечне реке, змије се пењу по дрвећу, а птице

${ }^{28}$ При томе, црвена боја је карактеристична за Богородицу, али је у исто време и симбол страдања Христа, који је пролио своју крв за спасење човечанства (Мршевић-Радовић, 2008, 16). 
склањају у изворе. Према веровању, у том рајском простору птице у канџама (или кљуну) преносе драгоцену течност беле боје, за коју се у фолклору сматра да осигурава бесмртност, а која је позната под именом „вода живота”. Према мишљењу Мршевић-Радовић, то рајско млеко је само „опредмећена вечита човекова жудња да се приближи рајском простору, бесконачном и самом богу и вера у њено остварење мери се јачином човекове жудње за њим” (v. Мршевић-Радовић, 2008, 20-22).

Голуб је симбол љубави, што се прецизније објашњава паром голубова: живети као голубови 'живети у љубави, добро се слагати' Овај, као и сви претходно поменути фразеологизми, одсликавају изразито позитиван однос говорника српског језика према овој животињи. То је посебно подржано симболиком женског представника ове врсте: голубица је симбол Светог Духа; бела голубица је симбол чистоте и безазлености према Јеванђељу. Након епизоде о Нојевој барци голубица носи маслинову гранчицу, која симболизује мир и склад (Gerbran, Ševalije, 2013, 238).

На околности које се могу описати као изобиље, благостање и срећа упућује се фразеологизмима печени голубови падају с неба, лете коме печени голубови у уста, печене шеве лете (коме) у уста (падаjу с неба), при чему се последње две варијанте могу још односити и на случајеве када се лагодан живот остварује без много труда и напора. Претпоставка је да су наведени изрази мотивисани библијским сценама у оквиру приче о Мојсијевом избављењу јеврејског народа из Египта. Наиме, стигавши у пустињу Син, израелски народ, мучен глађу и жеђу услед мукотрпног и дугог путовања, проклињао је сопствену судбину и гневно оптуживао своје вође. На Мојсијеву молбу да нахрани изгладнели народ, Господ шаље препелице с неба (Библ., Друга књига Мојсијева, 16, 13). Иако се ово Мојсијево чудо у науци може објаснити сасвим природним појавама ${ }^{29}$, оно оставља довољно снажан утисак те постаје сликовита основа за развој фразеолошких јединица. Премда се цела библијска слика може схватити и алегорично

${ }^{29} \mathrm{C}$ афричког континента у пролеће се у огромним јатима препелице селе у Европу. Исцрпљене слећу на земљу, а пошто су толико изнемогле, тамошњи становници их хватају голим рукама. Према мишљењу 3. Косидовског $(1993,173)$, Израелци су највероватније наишли на једно такво јато и искористили срећну околност. 
тако да птица симболизује небеску храну као духовни извор живота, у фразеолошкој семантици она индукује компоненту материјалног богатства и благостања. Идеја о птици која је пала с неба, а при томе је печена, већ припремљена за јело, на секундарном, фразеолошком плану остварује се као постигнуће без уложеног труда и напора.

У фразеологизму кукати (закукати) као сиња кукавица 'јако плакати, заплакати’ одражава се симболичка вредност ове птице и етиологија њеног статуса у животињској слици света. Кукавица је добила назив по начину оглашавања, и то не само у словенским него и у многим индоевропским језицима (Ђорђевић, 1958, 3). По народној традицији, има женску симболику. У њеном кукању препознаје се неутешан плач и нарицање. У складу с тим су легенде о њеном настанку: кукавица је постала од жене или девојке која је туговала за погинулим или изгубљеним мужем или га је узалудно дозивала; такође, у кукавицу се претворила жена или девојка која је непрекидно оплакивала смрт брата, сина или оца (Толстој, Раденковић, 2001, 315; Ђорђевић, 1958, 3-20; Гура, $2005,513)$. Њено оглашавање сматрано је злокобним предзнаком: оно најављује смрт, несрећу или какву другу невољу (Толстој, Раденковић, 2001, 316; Ђорђевић, 1958, 3-20). Из овог уверења изникао је израз закукаће (закукала је и сл.; завиће, завила је и сл.) њему (му, юој, јој и сл.) (ирна, сиња и сл.) кукавица (на слемену, кући и сл.) у значењу 'умреће (умро) му (јој и сл.) неко у кући, доживеће (доживео је, доживела је и сл.) велику жалост због нечије смрти или погибије ${ }^{30}$.

\section{3. Закључак}

Имајући у виду резултате анализе, могу се донети извесни лингвистички и лингвокултуролошки закључци. У лексички састав посматраних фразеологизама улазе називи само одређених врста птица. Реч је махом о животињама с којима човек остварује непосредан додир било због егзистенцијалне упућености на њих (кокошка, петао, гуска,

${ }^{30}$ У народном предању кукавицу у њеном јаду и жалости прате ластавица и змија, што се може видети на основу детаља из народних песама (v. Ђорђевић, 1958, 8-9). Кукавица има другачију симболику у белоруском језику (v. Голяк, 2007, 189). 
патка) било због близине њиховог станишта (врабац, голуб, лабуд, ласта, кукавица). Богато искуство, засновано на реалним и имагинарним својствима птица, које је човек акумулирао у дугом периоду суживота с њима, служи као основна информациона база за формирање фразеолошких јединица, стога је проблему њихове мотивисаности посвећена посебна пажња. У првом реду, мотивациону основу чине физичка својства птица (величина тела, изглед појединих његових делова, боја перја итд.), затим њихово оглашавање, кретање и уобичајени облици понашања. О овим особеностима човек стиче знања захваљујући својим чулима и користи их као изворни домен у концептуализацији других сегмената стварности, који су претежно усмерени на човека. Фразеолошка семантика формира се у знатној мери захваљујући процесима персонификације и метафоризације. Међутим, анализа показује да у семантичким фразеологизационим процесима у знатној мери учествују и стереотипне представе о птицама те њихова симболичка улога (тражити птичјег млека), која је уткана у митолошке и религијске системе више народа. Иако анализирани фразеолошки корпус открива однос говорника српског језика према појединим птичјим врстама, јасно је да је добијена слика овог сегмента животињског света извесним делом обележје многих европских народа, односно да је наслеђена из заједничког културноисторијског обрасца. То потврђују управо фразеологизми који су преузети из других језика (нпр. подметнути кукавичје јаје) или имају статус интернационализма (бела врана).

\section{Литература}

Апресян, Ю. Д. (1995). Интегральное описание языка и системная лексикография. Изабраные труды II. Москва: Школа „Языки русской культуры”.

Бартмињски, J. (2011). Језик - Слика - Свет. Прев. М. Бјелетић. Београд: SlovoSlavia.

Библ. - Свето писмо Старога и Новога завјета. Прев. Ђ. Даничић, В. С. Караџић. Београд: Британско и инострано библијско друштво.

Голяк, С. (2007). Аспекты лингвокультурного исследования фразеологии. „Славистика" бр. 11, стр. 186-193.

Гољак, С. (2013). Лингвокултуролошки аспекти устаљених поређења у српском и белоруском језику. „Научни састанак слависта у Вукове дане” бр. 42/1, стр. 495-507. 
Група за језичке технологије Универзитета у Београду. Корпус савременог српског језика, верзија SrpKor 2013. Д. Витас, М. Утвић. http://www.korpus.matf.bg.ac.rs.

Гура, А. В. (2005). Симболика животиња у словенској народној традииији. Београд: Бримо-Логос-Александрија.

Ђорђевић, Т. (1958). Природа у веровању и предању намег народа II. „Српски етнографски зборник" бр. 72.

Зыкова, И. В. (2015). Кониептосфера культуры и фразеология. Теория и методы лингвокультурологического изучения. Москва: Ленанд.

Косидовски, 3. (1993). Библијске легенде. Београд: Српска књижевна задруга.

Мршевић-Радовић, Д. (2008). Фразеологија и национална култура. Београд: Друштво за српски језик и књижевност Србије.

Оташевић, Ђ. (2012). Фразеолошки речник српског језика. Нови Сад: Прометеј.

Раденковић, Љ. (1996). Симболика света у народној магији Јужних Словена. Београд-Ниш: Балканолошки институт САНУ-Просвета.

РМС - Речник српскохрватског књижевног језика, т. I-VI. (1967-1976). Нови Сад: Матица српска.

РСАНУ - Речник српскохрватског књижевног и народног језика, т. I-. (1959-). Београд: Институт за српски језик САНУ.

Толстој, С., Раденковић, Љ. (ред.) (2001). Словенска митологија. Енциклопедијски речник. Београд: Zepter book world.

Телия, В. Н. (1996). Русская фразеология. Семантический, прагматический илингвокультурологический аспекты. Москва: Школа „Языки русской культуры”.

Шипка, М. (1998). Зашто се каже? Нови Сад: Прометеј.

[Apresjan, J. D. (1995). Integral'noje opisanije jazyka i sistemnaja leksikografija. Izabranije trudy II. Moskva: Škola „Jazyki russkoj kul'tury”.

Bartmiński, J. (2011). Jezik - Slika - Svet. Prev. M. Bjeletić. Beograd: SlovoSlavia.

Bibl. - Sveto pismo Staroga i Novoga zavjeta. Prev. Đ. Daničić, V. S. Karadžić. Beograd: Britansko i inostrano biblijsko društvo.

Goljak, S. (2007). Aspekty lingvoku'turnogo isledovanija frazeologiji. „Slavistika” br. 11, str. 186-193.

Goljak, S. (2013). Lingvokulturološki aspekti ustaljenih poređenja u srpskom i beloruskom jeziku. „Naučni sastanak slavista u Vukove dane” br. 42/1, str. 495-507.

Gura, A. (2005). Simbolika životinja u slovenskoj narodnoj tradiciji. Beograd: BrimoLogos-Aleksandrija.

Đorđević, T. (1958). Priroda u verovanju i predanju našeg naroda. „Srpski etnografski zbornik" br. 72 .

Zykova, I. (2015). Konceptosfera kul'tury i frazeologija. Teorija i metody lingvokul'turologičeskogo izučenija. Moskva: Lenand.

Grupa za jezičke tehnologije Univerziteta u Beogradu. Korpus savremenog srpskog jezika, verzija SrpKor 2013, D. Vitas, M. Utvić. http://www.korpus.matf.bg.ac.rs.

Kosidovski, Z. (1993). Biblijske legende. Beograd: Srpska književna zadruga.

Mršević-Radović, D. (2008). Frazeologija i nacionalna kultura. Beograd: Društvo za srpski jezik i književnost Srbije. 
Otašević, Đ. (2012). Frazeološki rečnik srpskog jezika. Novi Sad: Prometej.

Radenković, Lj. (1996). Simbolika sveta u narodnoj magiji Južnih Slovena. BeogradNiš: Balkanološki institut SANU-Prosveta.

RMS - Rečnik srpskohrvatskog književnog jezika, t. I-IV. (1967-1976). Novi Sad: Matica srpska.

RSANU - Rečnik srpskohrvatskog književnog i narodnog jezika, t. I-. (1959-). Beograd: Institut za srpski jezik SANU.

Tolstoj, S., Radenković, Lj. (red.) (2001). Slovenska mitologija. Enciklopedijski rečnik. Beograd: Zepter book world.

Telija, V. N. (1996). Ruskaja frazeologija. Semantičeskij, pragmatičeskij i lingvokul'turologičeskij aspekty. Moskva: Škola „Jazyki ruskoj kul'tury”.

Šipka, M. (1998). Zašto se kaže? Novi Sad: Prometej].

Barčot, B. (2017). Lingvokulturologija i zoonimska frazeologija. Zagreb: Hrvatska sveučilišna naklada.

Bunk, A., Opašić, M. (2010). Prilog kontrastivnoj analizi frazema sa zoonimskom sastavnicom u hrvatskome $i$ češkome jeziku. „Rasprave Instituta za hrvatski jezik i jezikoslovlje" br. 36/2, str. 237-250.

Gerbran, A., Ševalije, Ž. (2013). Rečnik simbola. Mitovi, snovi, običaji, postupci, oblici, likovi, boje, brojevi. Novi Sad: Stylos art-IK Kiša.

Kovačević, B. (2015). Crna ovca - bijela vrana - rijetka ptica. „Hrvatski jezik” br. 2/2, str. 31-32.

Matešić, J. (1982). Frazeološki rječnik hrvatskoga ili srpskog jezika. Zagreb: Školska knjiga.

Vidović Bolt, I. (2014). Životinja kao (ne)inteligentan čovjekov prijatelj. U: Životinje u frazeološkom ruhu. Ur. I. Vidović Bolt. Zagreb: Filozofski fakultet Sveučilišta u Zagrebu-FF-press. http://www.animalisticki-frazemi.eu/index.php/znanstveni-skupovi/znanstveni-skup-21-i-22-ozujka-2014/zbornik-radova. 15.10.2020. 